рівень сформованості національного світогляду майбутніх учителів музики засобами фольклорно-етнографічного мистецтва за визначеними критеріями: за мотиваційним (13,8 \%), когнітивно-аксіологічним (60,8 \%), діяльнісно-праксеологічним $(60,2 \%)$, що загалом дало 45,0 \%. Це підтверджує неналежний стан вишівської підготовки студентівмузикантів до світоглядної діяльності та зумовило необхідність пошуку шляхів її вдосконалення.

Виявлено, що загальний рівень мотивації щодо сформованості системності знань про національну картину світу та їі складники в майбутніх учителів музики є низьким, знання студентів здебільшого неглибокі, нечіткі, несистематизовані. Майбутні вчителі не володіють методичними знаннями й уміннями організації фольклорно-етнографічної діяльності школярів. Потенційні можливості використання творів українського фольклорноетнографічного мистецтва у змісті переважної більшості навчальних дисциплін та виховній роботі педагогічного вишу залишаються практично нереалізованими.

Узагальнення результатів констатувального експерименту підтвердило необхідність цілеспрямованого формування національного світогляду майбутніх учителів музики.

Обов’язковим перспективним напрямом дослідження є розгляд методики формування національного світогляду майбутніх учителів музики засобами фольклорноетнографічного мистецтва.

\title{
Література
}

1. Борисова С. В. Формування національної самосвідомості майбутніх учителів засобами українського музичного мистецтва : дис. на здобуття наук. ступеня канд. пед. наук : 13.00.04 / Борисова Світлана Володимирівна. - Луганськ, 2002. - 186 с. 2. Карпенчук С. Г. Теорія і методика виховання: [навч. посіб. для студ. вищ. пед. навч. закл.]/ Світлана Григорівна Карпенчук. - Київ : Вища школа, 2005. - 343 с. З. Потапюк Л. М. Формування світогляду учнів підліткового та юнацького віку у навчально-виховному процесі сучасної школи: дис. на здобуття наук. ступеня канд. пед. наук : 13.00.07 / Потапюк Л. М. . Тернопіль, 2002. - 186 с. 4. Сотська Г. І. Підготовка майбутнього вчителя образотворчого мистецтва до навчання учнів основної школи художнього конструювання: дис. на здобуття наук. ступеня канд. пед. наук : 13.00.04 / Сотська Г. І. - K., 2008. - 210 с.

УДК 378

Лариса Рикова

\section{СИСТЕМНЕ ВИКОРИСТАННЯ МОДЕЛЕЙ У ВИКЛАДАННІ ПРИРОДНИЧО- МАТЕМАТИЧНИХ ДИСЦИПЛІН ЯК ОДИН 3 ЕФЕКТИВНИХ МЕТОДІВ ФУНДАМЕНТАЛІЗАЦІЇ ПІДГОТОВКИ МАЙБУТНІХ ПЕДАГОГІВ}

Рикова Л. Л. Системне використання моделей у викладанні природничоматематичних дисциплін як один 3 ефективних методів фундаменталізації підготовки майбутніх педагогів.

На основі аналізу сутності і функцій фундаменталізації освіти запропоновано три дидактичні умови використання моделей у викладанні природничо-математичних дисциплін задля реалізації основних принципів фундаменталізації підготовки майбутніх педагогів.

Ключові слова: фундаменталізація освіти, використання моделей, підготовка майбутніх педагогів.

Рыкова Л. Л. Системное использование моделей в преподавании естественно- 
математических дисциплин как один из эффективных методов фундаментализации подготовки будущих педагогов.

На основе анализа сути и функций фундаментализации образования предложены три дидактических условия использования моделей в преподавании естественно-математических дисциплин с целью реализации основных принципов фундаментализации подготовки будущих педагогов.

Ключевые слова: фундаментализация образования, использование моделей, подготовка будущих педагогов.

Rykova L. L. Systemic use of models in the teaching of natural and mathematical disciplines as one of the effective fundamentalization methods of future teachers training.

Based on the analysis of the nature and functions of education fundamentalization three didactic conditions of use of models in teaching natural and mathematical disciplines for the purpose of realization of the basic principles of a fundamentalization of future teachers training have been offered.

Key words: education fundamentalization, the use of models, future teachers training.

У XXI столітті набули особливої гостроти (у багатьох, навіть найрозвиненіших, країнах) питання щодо кризи освіти: високі темпи накопичення нової інформації, динамічність розвитку науки і технологій привели до того, що система освіти виявилася нездатною забезпечити таку підготовку фахівців, яка залишалася б актуальною протягом тривалого часу. Зокрема, знання в галузі природничих дисциплін застарівають до завершення студентами вищого навчального закладу. Це світова проблема, яка у нашій країні постає особливо гостро, оскільки шкільна освіта у галузі природничих і математичних дисциплін перебуває на низькому рівні, про що свідчать результати ЗНО і висновки експертів. Одним із основних чинників незадовільного стану шкільної природничоматематичної освіти $€$ низький рівень підготовки учителів природничоматематичних дисциплін.

Практично у всіх педагогічних вищих навчальних закладах програми з природничих та математичних дисциплін настільки роз'єднані як за змістом, так і за часом вивчення, що випускники (бакалаври та магістри) одержують або «острівкові», або вузькоспрямовані знання, що не надає їм можливості повноцінно викладати у школі. Як результат, учитель природничо-математичних дисциплін не має єдиного погляду на світ в цілому, структурних уявлень про наш Всесвіт, Землю, природу. Розв’язання цієї проблеми науковці (М. БулановаТопоркова, М. Жалдак, К. Колін, С. Семеріков, О. Суханов) убачають у фундаменталізації сучасної освіти. К. Колін, зокрема, пише: «Нині украй необхідно не просто підвищення рівня освіченості людей, а й формування нового типу інтелекту, іншого образу мислення, що визначає ставлення людей до економічних, технологічних, соціальних і інформаційних реалій навколишнього світу, що швидко змінюється. У цьому зв'язку у 21 столітті освіта повинна стати безперервним процесом, який буде тривати протягом усього життя людини» [1, с. 60]. Тому учитель повинен бути здатним не тільки передати поточні знання і сформувати єдині уявлення про світ у цілому, а й навчити учнів «здобувати» нові знання і сформувати переконаність у тому, що вчитися потрібно протягом усього життя. Таке завдання здатен розв'язати тільки вчитель, який отримав у ВНЗ фундаментальні знання.

У літературі пропонується різноманітність суджень щодо поняття «фундаменталізація освіти», які можна розділити на дві групи. У більшості випадків автори обмежуються 
окремим (вузьким) розумінням фундаменталізації освіти. Це обмеження, як правило, пов’язане межами конкретної науки або конвертованістю набутих знань. Так, Т. Бороненко та Н. Рижова вважають, що найбільш важливим компонентом фундаменталізації освіти є їі інформатизація; на думку М. Литвиненко, фундаменталізація означає пріоритет теоретичних (випереджальних) знань, тобто фундаменталізація виконує випереджувальну функцію в освіті. Інша група суджень сприяє більш загальному розумінню явища фундаменталізації. Із вище викладеним корелює думка О. Суханова, який уважає концепцію фундаменталізації найважливішим компонентом нової освітньої парадигми: фундаменталізація освіти категорія якості освіти й освіченості особистості. С. Семеріков уважає концепцію фундаменталізації для вищої освіти системоутворювальною, зазначаючи, що «процес її фундаменталізації є як поверненням до витоків сучасної університетської освіти, так і рухом до інтеграції до загальноєвропейського освітнього простору» [2, с. 279].

Доречно процитувати О. Суханова [3, с. 21]: «Фундаменталізація - це принципово нова якість сучасних освітніх систем, яка знаходить свою реалізацію у змісті освіти й методології навчального процесу, прийомах організації міждисциплінарних зв’язків». Подібні думки висловлюють О. Андреєв, В. Солдаткін, Л. Раїнкіна, які під фундаменталізацією пропонують розуміти системне збагачення навчального процесу фундаментальними знаннями й методами творчого мислення, виробленими фундаментальними науками, причому навчальні дисципліни повинні постійно збагачуватися досягненнями відповідних наук.

Як вихідне теоретичне положення фундаменталізації освіти береться ідея єдності світу, яка виявляється в загальному взаємозв'язку неживого, живого й духовного. Визначальну роль у фундаменталізації освіти відіграють фундаментальні науки, до яких відносять ті, чиї основні положення і поняття первинні, тобто не є наслідками інших наук. Це природничі науки, тобто науки про природу в усіх її виявах, - фізика, хімія, біологія, науки про космос, землю, людину тощо, а також математика, інформатика і філософія, без яких неможливе глибоке осмислення знань про природу.

Особлива роль на шляху революційних перетворень у системі освіти належить вищим навчальним закладам педагогічного профілю, оскільки основи фундаментальної освіти закладаються в загальноосвітній школі, а провідниками цього є випускники педагогічних навчальних закладів.

Слід констатувати, що питання фундаменталізації освіти в сучасній педагогічній літературі, переважно, представлені в загальному вигляді, тобто стосуються якості, принципів і змісту освіти. Залишається відкритою проблема проникнення ідей фундаменталізації в систему відбору методів, прийомів, засобів навчання. У цьому смислі слід мати на увазі, що фундаменталізація передбачає цілісність освіти, включає до себе всі імплікаційні ланцюжки від перших ланок до останніх, тобто знання основних законів природи повинні містить повний комплекс відповідних обгрунтувань i доказів. Формулювання законів, основ, принципів у галузі природознавства і математики $\epsilon$ результатом кінцевих узагальнень, в основу яких покладено деякі проміжні узагальнення; останні, у свою чергу, грунтуються на деяких початкових узагальненнях і т. д. Отже, «механізм» фундаменталізації $\epsilon$ багатоступеневим. Причому багатоступеневість теж $\epsilon$ багатоплановою. Вона спостерігається у процесі вивчення конкретного об’єкта чи явища; спостерігається вона й при вивченні групи однотипних об’єктів або явищ; спостерігається багатоступеневість у межах цілої науки і навіть у межах всього природознавства. Така 
багатоступеневість напевно має місце і в межах усієї фундаментальної освіти (у тому числі гуманітарний складник).

Аналогічну позицію у спрощеному варіанті висловлює О. Суханов, аналізуючи питання фундаменталізації освіти. 3 усієї багатоступеневості він вибрав три основних ступені (рівні), які забезпечують фундаментальні знання.

Один із рівнів пов’язаний із опануванням методології наукового пошуку на прикладах вивчення окремих явищ, процесів, об’єктів у межах конкретних наук. Сюди віднесено методологію постановки задачі, планування експерименту, отримання й обробка масиву даних, феноменологія, теоретичні узагальнення, після яких ці етапи повторюються тощо. Другий рівень пов’язаний з аналізом результатів, отриманих у процесі вивчення цілого класу явищ, об’єктів, процесів, їх порівнянням і виробленням системних уявлень у конкретний період розвитку науки. У перспективі формуються нові системи уявлень, що є результатами нових експериментів і отримання даних, які не укладаються в межі усталеної системи уявлень. У такий спосіб еволюціонують теорії в кожній із фундаментальних наук. Прикладом такої еволюції, наприклад, у фізиці, є: 1) класична механіка - хвильова механіка - квантова механіка; 2) атом за Резерфордом - за Планком - за де-Бройлем i Шредингером; можна навести також багато інших прикладів. Нарешті, третій рівень пов’язаний з міжпредметними зв'язками, виявленням найбільш загальних законів природи як кінцевої мети нової освітньої парадигми. Нині, на думку О. Суханова, про це можна казати лише як про тенденцію, і його досягнення можливе в досить далекій перспективі.

Отже, у рамках трирівневого механізму фундаменталізації сформулюємо три відповідні аспекти:

1) хронологічна варіанта уявлень про об’єкти;

2) хронологічна варіанта систем уявлень (теорій) у рамках кожної природничої та математичної наук;

3) хронологічна варіанта філософських узагальнень у рамках міжпредметних зв’язків.

Далі слід говорити про конкретні методи й прийоми реалізації кожного із вказаних аспектів. Метою даної роботи є дослідження педагогічних умов використання моделей у процесі викладання природничо-математичних дисциплін для реалізації основних аспектів фундаменталізації вищої освіти.

На сучасному етапі саме поняття «модель», іï призначення, можливості, форми суттєво збагатилися. Навіть мотивації вибору моделі в тому чи тому випадку набули різноманіття. Часто, наприклад, мотивацією вибору моделі $\epsilon$ аналогізм. Причому можуть мати місце різні подібності між моделлю й оригіналом: зовнішня подібність, математична подібність, фундаментальна подібність тощо. Вибираючи модель-аналог з більш вивченого розділу науки, можна робити припущення про оригінал до початку його дослідження. Етапи пізнання максимально наближені за подібністю в різних природничих науках.

Постає питання про те, які моделі повинні застосовуватись у навчальному процесі. По-перше, оскільки навчальний предмет відображає наукову галузь, у навчальній діяльності повинні знайти відгук моделі, що використовуються в науці. Як приклади таких моделей можуть бути усі моделі атома, атомного ядра, такі моделі, як «матеріальна точка», «точковий заряд», лінійний осцилятор тощо. Хоча у викладанні успішно використовується низка наукових моделей, окремі з них є складними для сприйняття (порушуються дидактичні принципи систематичності й послідовності та посильної складності). Використання наукових моделей у навчальному процесі потребує попереднього дидактичного опрацювання. Наприклад, моделі кристалічних твердих тіл відпочатку вивчаються як бездефектні 
утворення (кожна кристалічна гратка є такою моделлю), а потім поступово уводяться різні дефекти. По-друге, у викладанні використовуються ті моделі, які не $є$ результатом або відображенням процесу наукового дослідження, а мають суто методичне походження.

Підкреслимо, що якщо структурні моделі обмежуються констатацією різних сторін об’єктів вивчення, то моделі, що ілюструють природу переходів «як» - «чому» - «навіщо», безумовно, є функціональними.

Дидактичний аспект $є$ загальною властивістю, яка притаманна всім навчальним моделям. Дидактичний аспект означає, що навчальна модель має низку властивостейпростота, доступність, легкість побудови та оперування ними в навчальній ситуації [4, с. 83].

Підкреслимо таку особливість. Якщо в науці найбільш важливою є остання комірка на еволюційному шляху, то в освіті не настільки важливою $є$ ця остання комірка порівнянно 3 усім шляхом, особливо з переходами від однієї комірки до іншої, оскільки саме в цьому випадку зосереджена максимальна концентрація методології досліджень, що, як описано вище, необхідно для фундаменталізації освіти. Отже, в межах одного часового періоду (однієї комірки) очевидні три «ділянки» на шляху отримання фундаментальних знань: 1) вивчення конкретних явищ (об’єктів) у межах конкретних наук; 2) феноменологічний опис результатів експериментів з подальшим створенням системи уявлень (теорії) в межах кожної науки; 3) виокремлення найбільш загальних властивостей, принципів і законів з усіх природничих наук, які об’єднані у єдину систему поглядів про природу.

Відповідно до викладеного можна виокремити три основні напрямки використання моделей із метою фундаменталізації освіти: перший напрям пов'язаний із використанням послідовностей моделей під час вивчення конкретних явищ, об’єктів, процесів, другий - 3 використанням послідовностей моделей у вивченні етапів розвитку науки в цілому, а третій - з використанням моделей-аналогів при здійсненні міжпредметних зв’язків. У нашій роботі ці три напрямки знайшли своє відображення у вигляді трьох дидактичних умов.

Перша дидактична умова накладається на процес вивчення деякого конкретного об’єкта з певної групи об’єктів, що складають деякий розділ (підрозділ) конкретної природничої або математичної науки. Спочатку (практично в усіх випадках) вивчається структура об’єкта шляхом безпосередніх спостережень, а також за допомогою розроблених експериментальних методик. Результати оформлюються у вигляді таблиць, малюнків, схем, які надалі подаються у вигляді сукупності (в цілому) за допомогою оптимальної структурної моделі (наприклад, геометричної). Далі властивості об’єкта, що спостерігаються, зіставляються 3 його дослідженою структурою, після чого визначаються залежності між властивостями та структурою, а також між самими структурними одиницями. У результаті викриваються деякі причинно-наслідкові зв'язки, які звичайно подаються у вигляді функціональних моделей (наприклад, математичних). Подальше дослідження об’єкта звичайно супроводжується появою нових (раніше невідомих) властивостей об’єкта, для пояснення яких не вистачає даних про відому структуру об’єкта і відомих залежностях. Здійснюється наступний крок «вглиб» об’єкта, виявляються нові структурні одиниці, уточнюється структурна модель. Слідом за цим з'являються нові функціональні моделі, тобто нові залежності. Наступний крок уточнює (або змінює) структурну модель, що супроводжується з'ясуванням нових залежностей, тобто появою нових функціональних моделей тощо. Саме в такий спосіб виникає чергування структурних і функціональних моделей, які перебувають у тісному органічному взаємозв'язку, породжують одна одну. Як приклад можна навести будь-який «відрізок» розвитку уявлень як у бік мікросвіту, так і в бік макросвіту. Неможливо без чергування структурних і функціональних моделей пройти 
ланцюжок «Земля - Сонячна система - зоряні скупчення - Чумацький шлях - ...», також як і в бік «тіло - молекула - атом - ядро атома (нуклони) - мезони - ферміони - ...». У математиці класичним прикладом такого багатоступінчастого алгоритму $є$ шлях, який веде до розуміння найбільш важливого об’єкта в математичному аналізі - інтеграла за мірою. Основні етапи цього шляху - інтеграл на сегменті - криволінійний інтеграл - подвійний інтеграл - поверхневий інтеграл - потрійний інтеграл і так далі.

Отже, глибоке вивчення будь-якого конкретного об’єкта як у природознавстві, так і в математиці реалізується поетапно. На кожному етапі створюється уточнена (порівнянно 3 попереднім етапом) структурна модель об’єкта і функціональна модель, детермінована нею, яка характеризує причинно-наслідкові зв'язки між структурними одиницями і властивостями об'єкта, що спостерігаються. Тому перша дидактична умова полягає у взаємозумовленому використанні структурних і функціональних моделей, що породжують одна одну $і$ органічно пов'язані між собою.

Друга дидактична умова пов’язана з еволюцією конкретної природничо-математичної науки в цілому. Історія розвитку природничо-математичних наук свідчить, що на зміну одним теоріям приходять інші; це відбувається тоді, коли наявна теорія перестає задовольняти сучасну практику. Основою утворення нових теорій $є$ нові, революційні ідеї або революційні результати експерименту, які не можуть бути поясненими в межах наявної теорії. Вони є основою нових уявлень про об’єкти вивчення; при цьому частіше за все нова теорія не відкидає усталеної, а поглинає їі, окреслюючи межі їі застосовності. Наприклад, перший етап, з якого розпочинається розвиток оптики як науки, є узагальненням законів, що починається з законів про прямолінійне розповсюдження світла, відбиття та заломлення. Ця теорія має назву геометричної оптики. Геометрична оптика уважалась непорушною протягом багатьох століть, доки розвиток експериментальної техніки не дозволив спостерігати такі явища, як інтерференція і дифракція світла. В усіх інтерференційних і диференційних явищах світло потрапляє в область геометричної тіні, що не може бути пояснено за допомогою законів геометричної оптики. Тому виник новий розділ оптики - хвильова оптика, у межах якої були не тільки пояснені такі явища, як інтерференція, дифракція, дисперсія, поляризація світла, а й були теоретично обгрунтовані усі закони геометричної оптики із зазначенням меж їх застосовності. Хвильова оптика стала наступною ланкою в системі уявлень про світло.

Подальший розвиток експериментальної техніки супроводжувався відкриттям нових явищ, які не могли бути описані за допомогою хвильової оптики. До таких явищ передовсім слід віднести фотоефект, явища поглинання і випромінювання світла атомами. Для пояснення цих та інших явищ було розроблено нову теорію, яка називається квантовою оптикою. Відповідно були створені квантові моделі, які ілюстрували вищеописані явища. Квантова теорія не закреслила хвильову, а доповнила їі, також указавши межі застосовності (квантово-хвильовий дуалізм). Отже, квантова оптика стала третьою ланкою у вивченні світла.

Такі ланцюжки моделей систем уявлень у природничих і математичних науках ми називаємо еволюційними ланцюжками моделей, що містять у собі як окремі ланки всі етапи розвитку конкретної науки.

Дослідження еволюційних ланцюжків моделей дозволило визначити їх інтегральну, історико-філософську та детермінуючу функції в навчанні. Використання еволюційних ланцюжків моделей є другою дидактичною умовою підвищення якості підготовки вчителів природничо-математичних спеціальностей. 
Розкриття дидактичного потенціалу навчальних моделей повною мірою можливе тільки за умов науково обгрунтованої опори на основні механізми мислення, серед яких у теорії моделювання особливе місце належить аналогії, яка $є$ найважливішим методом пізнання і одним з методів моделювання. У різних розділах природознавства і математики є аналоги як за структурою, так і за видами математичних описів. Усім відома, наприклад, «планетарна модель атома», створена англійським фізиком Ернестом Резерфордом, який для відображення структури атома використав структуру сонячної системи. Більш глибокий приклад: маса (m), момент інерції (I), коефіцієнт жорсткості (k), електрична ємність (C), магнітна індуктивність (L) тощо є кількісними мірами однієї властивості матерії - інертності, тобто будь-яка з цих величин може бути моделлю для всіх інших.

Суперпозиція уявлень 3 різних галузей знань сприяє цілісному сприйняттю кожного об’єкта дослідження, яке грунтується на існуванні найбільш загальних закономірностей. Слід відзначити, що погляди на певну науку «очима» інших наук виявляють подібні структуру і змістове наповнення усіх природничих наук - кожна структурна одиниця в природничій науці має аналоги в інших природничих науках. Проілюструємо це математичними формулами для обчислення енергії в різних розділах фізики: формула для обчислення кінетичної енергії поступального руху (1), кінетичної енергії обертального руху (2), енергії пружної деформації твердого тіла (3), енергії електричного поля зарядженого конденсатора (4), енергії магнітного поля соленоїда (5).

$$
W_{k \text { пост }}=\frac{m v^{2}}{2}(1), W_{\text {коб }}=\frac{\operatorname{Im}^{2}}{2}(2), E_{\text {пр деф }}=\frac{k x^{2}}{2} \text { (3), } E_{\text {ел }}=\frac{C U^{2}}{2} \text { (4), } E_{\text {магн }}=\frac{L I^{2}}{2} \text { (5). }
$$

Подібність цих формул, яка є очевидною, не випадкова. Їх аналогічність свідчить про те, що наведені формули є відображенням однієї і тієї ж кількісної залежності - енергії різних видів руху матерії від величин, що характеризують опірність усіх видів руху матерії своїй зміні.

Отже, у навчально-пізнавальній діяльності застосування методу аналогії відкриває нові можливості щодо підвищення ефективності навчання. Ми визначили такі функції моделей-аналогів у навчанні: пояснювальну, ілюстративну, інтерпретуючу, евристичну, системоутворювальну, світоглядну. Сукупність цих функцій моделей-аналогів через функцію інтелектуалізації забезпечує досягнення гнучкості та системності знань майбутніх учителів, оволодіння ними прийомами евристичного мислення, досягнення спроможності передбачення властивостей об’єктів вивчення, формування розуміння єдності фундаментальних законів природи, досягнення сформованості наукової картини світу. Отже, використання моделей-аналогів $є$ третьою дидактичною умовою у змісті підготовки вчителів природничо-математичних спеціальностей.

Описані вище три дидактичні умови не слід розглядати ізольовано одну від іншої. Основні дидактичні цілі можуть бути досягнуті саме в комплексному застосуванні цих умов, хоча застосування кожної сприятиме досягненню позитивних результатів. Застосування визначених дидактичних умов у взаємозв'язку сприяє фундаменталізації освіти шляхом реалізації тріади: перша дидактична умова спрямована на оптимізацію вивчення окремих об’єктів, явищ, процесів; виконання другої дидактичної умови оптимізує вивчення наукових теорій у межах певної навчальної дисципліни у процесі їх еволюції; третя дидактична умова 
забезпечує узагальнення в межах усього природознавства i математики, що складає основу світорозуміння.

Отже, аналіз процесів вивчення окремих об’єктів або явищ, груп об’єктів і явищ у природничих і математичних дисциплінах, а також загальних законів, що виявляються в усьому комплексі природничо-математичних дисциплін, призвів до трьох дидактичних умов використання моделей у викладанні цих дисциплін. Перша дидактична умова стосується вивчення окремих об’єктів або явищ (особливо складних) і полягає у взаємозумовленому використанні структурних і функціональних моделей, що породжують одна одну й органічно пов’язані між собою. Друга дидактична умова полягає у використанні еволюційних ланцюжків моделей і $є$, по суті, дидактичними засобами, що функціонально визначають той теоретичний шлях, який пройшла кожна з природничих і математичних наук до нинішнього часу. Третьою дидактичною умовою є використання моделей-аналогів, що, з одного боку, допомагає за допомогою більш досліджених предметних галузей вивчати менш досліджені, а, з іншого боку, сприяє викриттю найбільш загальних закономірностей у природі. Розуміння цих закономірностей по суті й представляє собою світорозуміння. Запровадження трьох викладених дидактичних умов сприяє реалізації основних функцій фундаменталізації освіти, включаючи системно-інтегративну, системно-розвивальну, функцію інтелектуалізації тощо. Це сприяє, в свою чергу, підвищенню рівня відповідних якостей знань: повноти, глибини, гнучкості, системності.

\section{Література}

1. Колин К. К. Информационный подход как фундаментальный метод научного познания / К. К. Колин // Педагогическая информатика. - 1998. - № 1. - С. 59-69. 2. Семеріков С. О. Фундаменталізація навчання інформатичних дисциплін у вищій школі : [монографія] / С. О. Семеріков. - Кривий Ріг : Мінерал; Київ: НПУ ім. М. П. Драгоманова, 2009. 3. Суханов А. Д. Концепция фундаментализации высшего образования и ее отражение в ГОСах / А. Д. Суханов // Высш. образ. в России. - 1996. - № 3. - С. 17-24. 4. Фридман Л. М. Моделирование в учебной деятельности / Л. М. Фридман // Формирование учебной деятельности школьников / [под ред. В. В. Давыдова и др.].Москва : Педагогика, 1982. - С. 73-86.

УДК 378.14:371.214.46

\section{Олена Семеніхіна, Володимир Шамоня,} Ольга Удовиченко, Артем Юрченко

\section{ПРОБЛЕМА ФОРМУВАННЯ ВМІНЬ ІНТЕРПРЕТУВАТИ «КОМП’ЮТЕРНИЙ» РЕЗУЛЬТАТ У ПІДГОТОВЦІ ВЧИТЕЛЯ ФІЗИКО-МАТЕМАТИЧНОГО ПРОФІЛЮ}

Семеніхіна О. В., Шамоня В. Г., Удовиченко О. М., Юрченко А. О. Проблема формування вмінь інтерпретувати «комп’ютерний» результат у підготовці вчителя фізикоматематичного профілю.

У статті описано проблему формування умінь адекватно інтерпретувати результат, одержаний засобами IT. Зазначено про можливі шляхи її розв’язання: формування теоретичних знань поряд з напрацюванням умінь критично оцінювати результат, аналізувати типові помилки, наводити контрприклади, використовувати тестові задачі тощо. Коротко описано досвід їх реалізації в підготовці вчителя фізико-математичного профілю.

Ключові слова: інтерпретація, формування вмінь інтерпретувати, інтерпретація комп’ютерного результату, підготовка вчителя. 